\title{
Increase of Onion Productivity by Regulation of Growing Technology Elements
}

\section{Svetlana Avdeenko, Aleksey Avdeenko, Igor Fetyukhin and Natalya Ryabt- seva}

Don State Agrarian University, Russia

ORCID:

Svetlana Avdeenko: http://orcid.org/0000-0002-6632-7589

Aleksey Avdeenko: http://orcid.org/0000-0003-4975-8085

\section{Abstract}

This article describes the impact of growth regulators used as foliar dressing on the high-quality commercial production of Mars and Candy $F_{1}$ hybrid onion bulbs grown in the Rostov Region. The highest yield of finished product per 1 thousand $\mathrm{m}^{2}$ of leaf area and 1 thousand units of photosynthetic potential (PSP) was observed when the Candy and Mars hybrids were treated with Novosil (3.9-4.1 t and 45.0-47.0 kg, respectively), which also produced the highest rates of net photosynthesis productivity: $8.5-8.7 \mathrm{~g} /$

Corresponding Author:

Svetlana Avdeenko

awdeenkoss@mail.ru

Published: 5 April 2021

Publishing services provided by

Knowledge E

(c) Svetlana Avdeenko et al. This article is distributed under the terms of the

Attribution License, which

permits unrestricted use and

redistribution provided that the

original author and source are

credited.

Selection and Peer-review unde the responsibility of the DonAgro Conference Committee.

\section{G OPEN ACCESS} $\mathrm{m}^{2}$ per day. The effect of the agent on growth processes was slightly more effective in the Candy hybrid. It was established that the use of Novosil and Immunocytophytes foliar dressing in growing technology makes it possible to obtain the Mars and Candy hybrids at the level of 49.0-50.1 $\mathrm{t} / \mathrm{ha}$, reduce the consumption of additional irrigation water per unit of production and improve the quality of commercial onion bulbs and their storage for a long winter period. The increase in storage resulting from the use of Novosil occurred due to the decrease in the natural loss and mass of the sprouted bulbs.

Keywords: onion, hybrid, yield, stimulant fertilizer, storage, quality.

\section{Introduction}

The bulb onion market in 2017 was characterized by a reduction in the supply of domestic goods, due to the low production volume in 2016, as well as the fact that the crop had short shelf life and was also affected by various fungal diseases. The reduction in yields also affected open-field vegetable growing as a whole. In addition, the rise in prices for goods affected the onion market. In the Southern District, prices rose by 30-50\%. In Rostov-on-Don in the small wholesale segment the average prices for onions amounted to 10.5 rubles / kg September 2017, which was $12.5 \%$ lower than in August and 38.2\% lower than in July [1].

In our country, more than 100 types of vegetable plants from 23 botanical families are cultivated, which differ significantly in biological characteristics, temperature, water, 
air modes of cultivation, soil fertility requirements and reactions to the use of macroand micronutrients. During nutrient bottlenecks, there are signs of starvation of vegetable plants. It is very important to notice these signs in time and apply appropriate dressing. The delay of the introduction of the missing elements leads to the decrease in yield and quality of vegetables. Russian and foreign companies currently produce the extensive range of various mineral, organic, organomineral, trace elements, amino acid, microbiological, peat, humic fertilizers and subsoils and the number of proposed synthetic and natural growth regulators is already approaching the thousand. It is quite difficult for inexperienced growers to understand what is useful in this amount of the proposed variety [2].

The soil and climatic conditions of the South of Russia and the Rostov Region, in particular, allow cultivating onions in summer crop and obtain high yields of excellent quality [3]. However, even the average yield of $41 \mathrm{t} / \mathrm{ha}$ is not the limit for onions. Based on the data of Avdeenko S.S., Bondarev I.I. [4], in the conditions of the Rostov region, using a complex of factors (irrigation, fertilizer and green manure in a complex action), yields up to $60 \mathrm{t} /$ ha can be obtained.

Onions became the most common vegetable crop in the Rostov region. The main volumes of production are exported to the center and the Northern regions [4]. Onions are considered to be the most valuable food and are more important in human life. First, it has nutritional value because it is rich in carbohydrates and nitrogenous substances. According to the Institute of Nutrition of Russian Academy of Medical Sciences, the rate of onion consumption per capita per year should be at least $8.2 \mathrm{~kg}$, including $2.2 \mathrm{~kg}$ of bulb onion [5].

Unfortunately, in the current situation it is possible to confidently state that the recommended rate of onion consumption is not respected for a number of reasons. One of the main reasons for this situation is the still insufficient level of crop productivity in the region, and since the region provides the need for onions, mainly due to its own resources, agricultural science needs to look for ways to increase the yield and improve the quality of bulb onion, including storage.

The works of Chinese and Indian scientists are devoted to the assessment of the impact of the use of bioregulators, irrigation and organic fertilizers, and the peculiarities of their effect on the productivity and quality of onions [6-7].

According to the opinion of the authors [8], the main promising ways to develop the production of onion in the conditions of the Veselovsky district of the Rostov Region may include the following: introducing a new varietal composition into production; wider use for of new agrochemicals with improved quality for growing onions (for example, for 
weed control; for preparing seeds for sowing, the use of fertilizers and growth stimulants with immunomodulating properties, etc.); the expansion of the modern machine-tractor fleet for universal use (including irrigation); ensuring long-term storage of the products obtained without exporting from the manufacturer and the possibility of its processing. In this regard, the relevance of research in this area is undoubtedly high.

\section{Methods and Equipment}

\subsection{Methods}

The main purpose of the work is to study growth stimulants on hybrids of onion in summer crop on irrigation, which can really increase the yield and improve its quality in relation to the Rostov region.

Variants of experiment: Water - control; Immunocytophyte - the first treatment in the phase of 4-5 leaves, the second - after 30-40 days, $20 \mathrm{~g} /$ ha. The flow rate of the working fluid is $300 \mathrm{I} / \mathrm{ha}$; Novosil - the first treatment in the phase of 4 leaves, the second - after 15 days, $20 \mathrm{ml} / \mathrm{h}$. The flow rate of the working fluid is $300 \mathrm{I} / \mathrm{ha}$; Buton - the first spraying in the phase of mass growth of leaves, the second - after 4-6 days, $20 \mathrm{~g} / \mathrm{ha}$. The flow rate of the working fluid is $400 \mathrm{I} / \mathrm{ha}$.

Candy $F_{1}$ and Mars $F_{1}$ hybrids were used in the experiment. The study was conducted according to the Methodology of experimental work in vegetable growing and melon growing (M., 1992) [9]. The accounting plot area was $20 \mathrm{~m}^{2}$; the placement of experience options was a systematic longline, in 4-fold repetition. Phenological observations were carried out, calculating the duration of the interphase periods. The synchroneity of seedlings, the dynamics of growth processes, yield and quality of the resulting products were also noted.

Onions were experimentally grown on the fields of Krasny Oktyabr CJSC of the Veselovsky District in 2016-2018 according to the technology of summer crop adopted in the region which implied sowing seeds into the soil in late March - the first decade of April under irrigation according to the scheme $55+15 \mathrm{~cm}$. During the growing season 8 sprinkling irrigation was carried out with a norm of $300 \mathrm{~m} 3$ / ha. The predecessor was cucumber.

CJSC Red October is located in the Veselovsky district of the Rostov Region. According to natural-economic division, this husbandry is included in the Central irrigated zone, subzone "B" [10]. The soil cover is represented by ordinary micellar-carbonate chernozems and meadow soils. The climate is arid with moderately hot summers and 
moderately cold winters. $420-500 \mathrm{~mm}$ of precipitation falls during a year and 190-250 $\mathrm{mm}$ falls and for a period with a temperature above 10 degrees. Hydrothermal index is 0.65-0.75, the average annual temperature is 8.6-9.3 degrees. The sum of temperatures for the active growing season is $3200-3400$ degrees.

\section{Results}

The growth stimulators used in the experiment influenced the phenological phases of onion vegetation. Thus, in Candy $F_{1}$ hybrid, the period from the appearance of mass seedlings to the green onion lodging was the shortest (78-79 days) when the plants were treated with Novosil and Immunocytophytes with a control period of 81 days. Our studies showed that Buton preparation did not reduce, but, on the contrary, increased the transition to green onion lodging by 6-7 days compared to Novosil and Immunocytophyte and by 4 days in comparison with the control sample. According to Mars $F_{1}$ hybrid, we noted a similar trend. By green onion lodging phase, the action of stimulants continued to affect the rate of passage of the phenological phases of the crop. Thus, hybrids in our experience responded to the use of Novosil and Immunocytophyte by shortening the period from green onion lodging to harvesting compared to the control sample for 5-7 days. The result of the positive effect of the preparations was a reduction in the total growing season by 11-14 days in comparison with the control sample, which can give a significant advantage during harvesting. It means that harvesting will take place in a more favorable weather period. The use of Buton preparation increases the duration of the growing season of hybrids in the experiment by 12-15 days.

The duration of the phenological phases with the use of growth stimulants was reflected in the growth processes of onion hybrids (Table 1).

The area of leaves of Candy hybrid in the experiment ranged from 9.3 thousand $\mathrm{m}^{2}$ / ha (minimum indicator) when it was treated with Novosil to 14.6 thousand $\mathrm{m}^{2}$ / ha (maximum indicator) when treating vegetative plants with Immunocytophyte stimulator. According to the Mars hybrid, the emerging trend in the formation of minimum indicators of leaf area during treatment with Novosil and maximum indicators during treatment with Immunocytophyte remained. Our studies allowed determining that the highest yield of finished products per 1 thousand $\mathrm{m}^{2}$ of leaf area and 1 thousand units of PSP were observed when processing plants Candy hybrid and Mars hybrid with Novosil agent: 3.9-4.1 tons and $45.0-47.0 \mathrm{~kg}$, respectively. Under the influence of this stimulant, the highestindicators of the net productivity of photosynthesis were also noted: $8.5-8.7 \mathrm{~g} /$ 
TABLE 1: Influence of growth regulators on the growth processes of onions (in average for 2016-2018) (Candy $\mathrm{F}_{1} /$ Mars $\mathrm{F}_{1}$ )

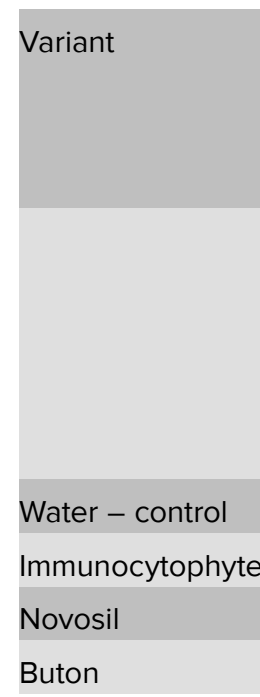

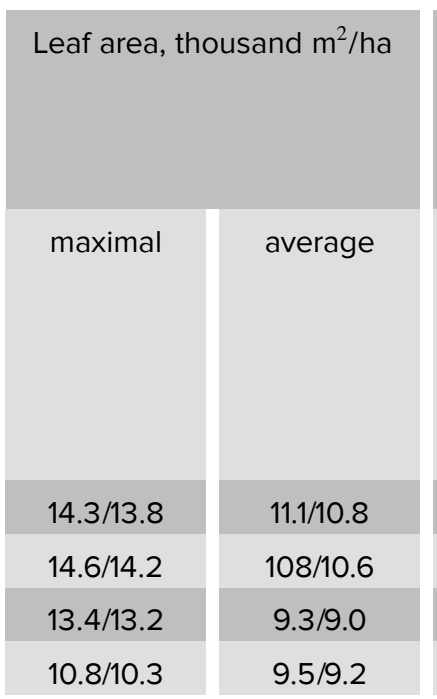

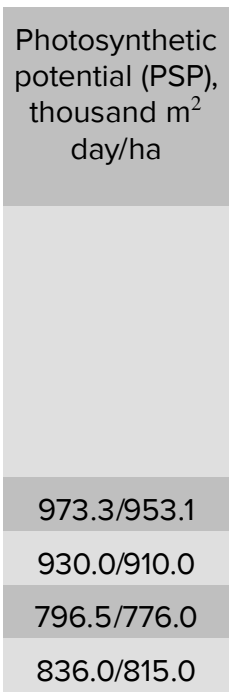

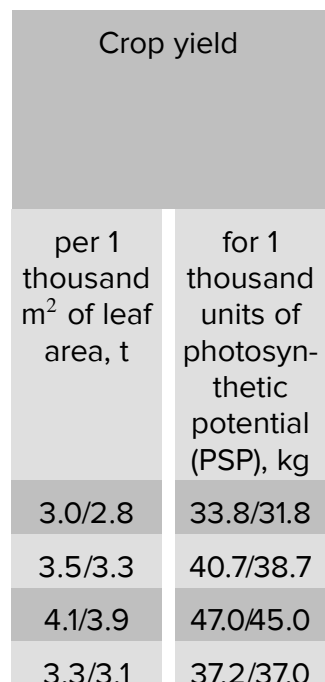

\begin{tabular}{|c|}
$\begin{array}{c}\text { Net photo- } \\
\text { synthesis } \\
\text { productiv- } \\
\text { ity, g / m2 } \\
\text { per day }\end{array}$ \\
\hline \\
\hline $7.4 / 7.2$ \\
\hline $7.3 / 7.1$ \\
\hline $8.7 / 8.5$ \\
\hline $5.9 / 5.7$
\end{tabular}

$\mathrm{m}^{2}$ per day. The effect of the agent on growth processes on Candy hybrid was slightly more effective.

If we consider the total yield, we can see that the weather conditions in 2018 made it possible to obtain higher yield indicators than in 2017 and 2016 although they were quite significantly different from the average annual conditions. This fact affected both Candy hybrid and Mars hybrid (Table 2).

According to Candy hybrid, in 2016 the maximum yield was observed for Novosil agent, and in 2017 and 2018. - for Immunocytophyte, and as a result, the average yield for 3 years of observation with a maximum rate of $50.1 \mathrm{t} /$ ha was obtained in this variant. However, all the stimulants studied in the experiment showed the increase compared to the control sample from 2.9 (Buton) to $7.2 \mathrm{t} /$ ha. These increases were significant (NRS 0.99-1.99 t / ha). The excess of productivity compared to control sample by $16.8 \%$ allows speaking about a more efficient use of additional moisture by onion plants obtained with irrigation water. Thus, in the control sample, the water consumption per 1 ton of production amounted to $55.94 \mathrm{~m}^{3}$ and in the best case, it decreased by 8.04 (Immunocytophyte agent), in the variants with Novosil and Buton - by 3.54-7.36 $\mathrm{m}^{3}$ compared to the control sample.

According to the data on Mars hybrid, in 2016 and 2018, the maximum yield was observed in Novosil agent, and in 2017 in Immunocytophyte, and as a result, the maximum average yield for 3 years of observation ( $49.2 \mathrm{t} / \mathrm{ha}$ ) was obtained in Novosil variant, unlike Candy hybrid, which had a maximum yield (50.1 $\mathrm{t} / \mathrm{ha}$ ) with application of Immunocytophyte. However, the difference in yield for the varianys using Novosil and Immunocytophyte was not significant: $0.2 \mathrm{t} / \mathrm{h}$. All stimulants studied in the experiment 
showed the increase compared to the control sample from 2.3 (Buton) to $6.3 \mathrm{t} / \mathrm{ha}$, and these increases were significant ( $\mathrm{NSP}_{05}$ 0.86-1.24 t/ ha). The increase by $14.7 \%$ increase in productivity compared to control sample indicates a more efficient use of hybrid Mars onions of additional moisture obtained with irrigation water. Thus, the water consumption per 1 ton of products in the best variants decreased by $6.96-7.16 \mathrm{~m}^{3} / \mathrm{t}$ (Immunocytophyte and Novosil) and $2.84 \mathrm{~m}^{3} / \mathrm{t}$ (Buton preparation) compared to the control sample (55.94 $\left.\mathrm{m}^{3} / \mathrm{t}\right)$.

TABLE 2: Yield of onion, depending on the processing of growth regulators

\begin{tabular}{|c|c|c|c|c|c|c|}
\hline \multirow[t]{2}{*}{ Variety } & \multicolumn{3}{|c|}{ Total yield by years, t / ha } & \multirow[t]{2}{*}{$\begin{array}{c}\text { In average, } \\
\text { t/ha }\end{array}$} & \multicolumn{2}{|c|}{$\begin{array}{c}\text { Dressing } \pm \text { according } \\
\text { to agent }\end{array}$} \\
\hline & 2016 & 2017 & 2018 & & t/ha & $\%$ \\
\hline \multicolumn{7}{|c|}{ Candy Hybrid $F_{1}$} \\
\hline Water - control & 38,8 & 44,1 & 45,8 & 42,9 & - & - \\
\hline Immunocytophyte & 45,4 & 49,6 & 55,4 & 50,1 & 7,2 & 16,8 \\
\hline Novosil & 46,1 & 48,7 & 53,4 & 49,4 & 6,5 & 15,2 \\
\hline Buton & 45,0 & 45,2 & 47,2 & 45,8 & 2,9 & 6,8 \\
\hline $\begin{array}{l}\text { Average for Candy Hybrid } \\
F_{1}\end{array}$ & 43,83 & 46,90 & 50,45 & 47,05 & 5,53 & 12,93 \\
\hline Increase to control, t/ha / \% & $5,03 / 12,96$ & $2,80 / 6,35$ & $4,65 / 10,15$ & $4,15 / 9,67$ & & \\
\hline $\mathrm{NSP}_{05} \mathrm{t} / \mathrm{ha} / \%$ & $0,99 / 2,25$ & $1,99 / 4,24$ & $1,36 / 2,69$ & & & \\
\hline \multicolumn{7}{|c|}{ Mars Hybrid $F_{1}$} \\
\hline Water - control & 40,1 & 44,0 & 44,6 & 42,9 & - & - \\
\hline Immunocytophyte & 45,7 & 49,7 & 51,6 & 49,0 & 6,1 & 14,2 \\
\hline Novosil & 46,4 & 48,5 & 52,6 & 49,2 & 6,3 & 14,7 \\
\hline Buton & 44,7 & 44,2 & 46,7 & 45,2 & 2,3 & 5,4 \\
\hline Average for Mars Hybrid $F_{1}$ & 44,23 & 46,60 & 48,88 & 46,58 & 4,90 & 11,43 \\
\hline Increase to control, t/ha / \% & $4,13 / 10,30$ & $2,60 / 5,91$ & $4,28 / 9,60$ & $3,68 / 8,58$ & & \\
\hline $\mathrm{NSP}_{05} \mathrm{t} / \mathrm{ha} / \%$ & $0,86 / 1,94$ & $1,18 / 2,54$ & $1,24 / 2,54$ & & & \\
\hline $\begin{array}{l}\text { In average by the year of } \\
\text { research and hybrids }\end{array}$ & 44,03 & 46,75 & 49,66 & 46,81 & & \\
\hline $\begin{array}{l}\text { The increase in the best } \\
\text { variant to the average, } t / \\
\text { ha } / \%\end{array}$ & $2,37 / 5,11$ & $2,95 / 5,94$ & $5,74 / 11,56$ & $3,29 / 7,03$ & & \\
\hline
\end{tabular}

According to the biochemical composition, the maximum values were revealed during the use of Novosil growth regulator. In dry matter, the $24 \%$, increase in Candy $F_{1}$ hybrid was found, in Mars $F_{1}$ hybrid the increase was $21.6 \%$, for the total sugar content the increase was $2.1 \%$ (Candy $F_{1}$ hybrid) and $1.8 \%$ (Mars $F_{1}$ hybrid). 


\section{Discussion}

In average for 2016-2017 the shelf life of onions of Candy $F_{1}$ during winter storage period by increased by $16.7 \%$ for samples treated with Novosil growth regulator, compared to the control sample, where water was sprayed, while the sprouted bulbs in this variant had a minimum amount of $10.7 \%$. According to Candy $F_{1}$ hybrid, the positive effect of Novosil on shelf life was also observed: in the experiment it was higher compared to the control sample by $9.2 \%$. During the use of Novosil stimulator, it was found that the increase in shelf life occurs due to the decrease in the natural loss and mass of sprouted bulbs.

\section{Conclusion}

Thus, the use of the technology foliar feeding of Novosil and Immunocytophyte allows obtaining harvests at the level of 49.0-50.1 $\mathrm{t} /$ ha for Mars and Candy hybrids, reducing the consumption of additional irrigation water per unit of production and improving the quality of bulb onions and their storage during long winter periods.

\section{Funding}

The work was carried out as part of the research activities of the faculty of the Federal State Budgetary Educational Institution of Higher Education of the Don State Agrarian University.

\section{Acknowledgement}

The authors would like to thank their colleague for their contribution and support to the research. They are also thankful to all the reviewers who gave their valuable inputs to the manuscript.

\section{Conflict of Interest}

The authors have no conflict of interest to declare. 


\section{References}

[1] Grigoriev, A. A. and Baranova, I. V. (2018). Analysis of the Onion Market in the Russian Federation for 2012-2016 Concept. In Modern research in the field of natural, technical and physical and mathematical sciences Kirov: Interregional Center for Innovative Technologies in Education.

[2] Borisov, V. A., et al. (2018). The System of Mineral Nutrition of Vegetable Crops. Moscow: EuroChem, p. 130.

[3] Bernikov, N. I. and Ognev, V. V. (2011). State and Prospects for the Development of Vegetable Growing in the Rostov Region. In Innovations in science, education and business are the basis for the effective development of the AIC. Persianovsky: Don GAU.

[4] Avdeenko, S. S. and Bondarev, I. I. (2013). The Complex of Agricultural Practices Increases the Yield and Quality of Onions. Potatoes and Vegetables, vol 1, pp. 5-7.

[5] Litvinov, S. S., Shatilov, M. V. (2014). Vegetable Growing - A New Impulse. Potatoes and Vegetables, vol 7, pp. 2-4.

[6] Wakchaure, G.C., Minhas, P. S., Meena, K. K. et al. (2018) Growth, bulb yield, water productivity and quality of onion (Allium cepa L.) as affected by deficit irrigation regimes and exogenous application of plant bio-regulators. Agricultural Water Management, vol 199, pp. 1-10.

[7] Lee, J. (2010) Effect of application methods of organic fertilizer on growth, soil chemical properties and microbial densities in organic bulb onion production. Science of Scientia Horticulturae, vol 124, pp. 299-305.

[8] Avdeenko, S. S. and Ispiryan, A. Z. (2019). The Influence of Growth Regulators on Growth Processes, Productivity, Quality and Shelf Life of Onions in the Central Irrigated Zone of the Rostov Region. In Resource Conservation and Adaptability in Technologies for Cultivating Crops and Processing Crop Products: Materials of the International Scientific and Practical Conference pos. Persianovsky: Don GAU.

[9] Litvinov, S. S. (1992). Methodology of Experimental Work in Vegetable Growing and Melon Growing. Moscow: Agropromizdat.

[10] Agafonov, E. V. and Poluektov, E. V. (1999). Soils and Fertilizers of the Rostov Region. Persianovsky: Don SAU. 